\title{
Replacing wheat flour with debittered and fermented lupin: effects on bread's physical and
} nutritional features

\author{
Elena Villacrés ${ }^{1}$, Paúl Cueva ${ }^{1,2}$, Milene Díaz ${ }^{2}$, Cristina M. Rosell ${ }^{3}$ \\ ${ }^{1}$ Instituto Nacional de Investigaciones Agropecuarias, INIAP. Quito, Ecuador. \\ ${ }^{2}$ Universidad Central del Ecuador, Facultad de Ciencias Químicas. Quito, Ecuador \\ ${ }^{3}$ Instituto de Agroquímica y Tecnología de Alimentos. IATA, CSIC. Valencia, España
}

Correspondence: Elena Villacrés. E-mail: elena.villacres@iniap.gob.ec

(1)

\section{Abstract}

In this study the breadmaking potential of lupin flour from L. mutabilis after being debittered (DLF) and solid state fermented (FLF) was evaluated in lupin-wheat breads. Different levels of substitution (10\%, $15 \%, 20 \%)$ were tested on dough rheology and the technological and nutritional (composition and in vitro digestibility indexes) properties of breads, as well as acceptability. Lupin weakened the dough during mixing, having shorter development time and stability, especially FLF. Less relevant was the effect of lupin flours along heating-cooling of the doughs recorded with the Mixolab. DLF and FLF significantly affected technological properties of the lupin-wheat breads at higher substitution $(>10 \%)$, particularly reducing bread volume, crust luminosity, crumb cohesiveness and resilience. Detrimental effects observed at the highest substitutions (20\%) were diminished when using FLF, although breads received lower score due to the acidic taste detected by panelists. Both lupin flours provided lupin-wheat breads with rather similar composition, rising the average content of proteins, fat and dietary fiber by $0.8,2.4,6.5$, respectively, compared to wheat breads. Likewise, lupin-wheat breads had significantly lower hydrolytic and glycemic indexes. Overall, debittered and fermented lupin could be used for enriching wheat breads, although better technological properties were observed with FLF.

Key words: lupin, debittering, fermentation, bread, nutrition, quality. 


\section{Introduction}

27 Wheat bread constitutes an important part of the diet and remains as staple food across the civilized world [1]. Nevertheless, sustainability issues and current consumers' demands have driven the latest innovations in bakery towards sustainable and healthy foods made of either whole grains, alternative grains or even legumes as substitutes for refined wheat. Likewise, wheat replacement in bread recipes for other grains allows reducing wheat importation in non-wheat producers' countries. Lupin (genus Lupinus) is an undervalued legume that some decades back was proposed for increasing the nutritional valued of bread [2]. However, only some years ago lupin seeds awakened growing interest due to its high protein content [3], observing very little changes in product acceptability up to $6 \%$ addition $[4,5]$. Increasing amounts of lupin flour (up to 20\%) decrease the bread volume and the crumb texture quality [6], but allows increasing the content in protein and dietary fiber, apart from the content of bioactive compounds like phenols and carotenoids [7]. Most of the studies reported for bread enrichment with lupin have been carried out using L. angustifolius (Blue Lupine with narrow leaves) [8] or L. albus

(White Lupine) [4]; although Lupinus mutabilis Sweet shows better adaptation to poor soils and extreme conditions limited information exists about its application in breadmaking. Despite the high nutritional value of lupin seeds, its use is very limited due to the presence of bitter compounds, specifically alkaloids derived from quinolizidine [9]. The aqueous debittering process, consistent in several washings, reduces the alkaloids content to safe levels [10], but it is quite costly in water and time consuming. This process can be more efficient using thermal treatments [11] and saline solutions $(0.5 \%$ (w/v) for seeds hydration and cooking [12]. Likewise, further nutritional improvement of lupin seeds could be obtained with the solid-state fermentation by using lactic acid bacteria [13] or fungi [14]. In fact, wholemeal lupin fermented with Lactobacillus sakei, Pediococcus pentosaceus or P. acidilactici could be added up to $10 \%$ as sourdough to wheat flour, improving the rheological properties of dough 
induced a further increase of protein levels [14], but there is no information about its potential application in breadmaking.

The objective of this research was to evaluate the impact of Lupinus mutabilis Sweet for wheat flour replacing in breadmaking, and to what extent the debittering and solid-state fermentation of lupin could affect the resulting dough and bread quality. With that purpose, different levels of lupin were tested and dough rheological properties as well as nutritional and technological quality of enriched breads were evaluated.

Materials and Methods

Materials

Lupinus mutabilis Sweet, variety INIAP-Andino 450, obtained by selection and evaluation from a germplasm population introduced from Peru in 1992, with the identification of ECU-2659. Commercial wheat flour (WF) for breadmaking (moisture content $14 \%$, ash $0.73 \%$, protein $14.30 \%$, gluten content $33.11 \%$ ) "Superior France" from Alsuperior S.A. (Quito, Ecuador) was used.

Production of debittered lupin flour (DLF) and fermented lupin flour (FLF)

The grains were debittered following the aqueous heat process [12]. One part of debittered grain $(5 \mathrm{~kg})$ was then dried in an air convection cabinet (Labolan HS122A, Navarra, Spain) at $50^{\circ} \mathrm{C}$ for $6 \mathrm{~h}$, it was cooled down to room temperature and ground in a mill using a $100 \mu \mathrm{m}$ sieve (Retsch KG -5657 Haan Remscheid, Germany), obtaining the debittered lupin flour (DLF). Other part of debittered grain (5 Kg) was subjected to solid state fermentation following the procedure described by Villacrés et al. [14]. Fermented grains were then dried and ground as above described, to obtain fermented lupin flour (FLF). Physical characteristics and chemical composition of flours

$71 \mathrm{pH}$ and total titratable acidity (TTA) were determined after homogenizing $10 \mathrm{~g}$ of flour with $90 \mathrm{ml}$ of 72 distilled water, and expressed as milliliters of $0.1 \mathrm{M} \mathrm{NaOH}$ needed to reach $\mathrm{pH}$ 8.3. Standard 
(920.39), dietary fiber (991.43) and ash (942.05) [15]. The mineral content was determined by atomic

75

76

77

78

79

80

81

82

83

84

85

86

87

88

89

90

91

92

93

94

95

96

absorption spectrophotometry in AA-7000 atomic absorption spectrophotometer (Shimadzu, Kyoto, Japan) following AOAC method 985.35, except for phosphorus that was colorimetrically analyzed [15].

\section{Dough characterization}

Mixolab (Chopin, Villeneuve-la-Garenne Cedex, France) was used to characterize the rheology of the doughs following the standard method AACC (54-60.01) [16]. The impact of the lupin flours (DLF and FLF) was evaluated by replacing wheat flour at three levels 10,15 and $20 \%$. $\mathrm{pH}$ and total titratable acidity (TTA) of lupin-wheat doughs were assessed as described previously for flours.

\section{Bread making}

Bread recipe, based on $100 \mathrm{~g}$ flour, was: $5 \mathrm{~g}$ sugar, $2 \mathrm{~g}$ salt, $9 \mathrm{~g}$ sunflower seeds oil, $4 \mathrm{~g}$ compressed yeast, $3 \mathrm{~g}$ dairy powder and the required water assessed in the Mixolab. Ingredients were mixed together in a mixer (Planetaria VFICB7B, Lombardía, Italy) for $7 \mathrm{~min}$. Dough was proofed in a cabinet at $37{ }^{\circ} \mathrm{C}$ and $90 \%$ relative moisture for $20 \mathrm{~min}$, then dough was divided $(-170 \mathrm{~g})$, shaped and placed into previously greased stainless steel trays, which were fermented for $1 \mathrm{~h}$ at $37^{\circ} \mathrm{C}$. Baking was carried out at $190^{\circ} \mathrm{C}$ for $25 \mathrm{~min}$ in an electric oven (Maquipan UHC-1, Florida, USA). Loaves were cooled down at room temperature for $30 \mathrm{~min}$

\section{Bread characterization}

Chemical composition of breads was assessed as described previously for flours. The texture was performed $24 \mathrm{~h}$ after the breads were baked, following the AACC method 74-09 [18] using a texturometer TA-XT2i, Stable Micro Systems, Godalming, UK. The crust and crumb color were performed using a Portable Spectrophotometer (Lange Spectro-Color d/8 ${ }^{\circ}$ model LZM 268, Chelmsford, United Kingdom) based on the CIE $L^{*}, a^{*}, b^{*}$ color system. The following attributes of visual sensation were measured: $L^{*}$ (luminosity), $C^{*}$ (chromatism) and $H^{*}$ (hue). The determination of 
specific volume was made according to the method AACC 10-05.01 [16], the hydrolytic and glycemic

98 index by the method described by Goñi et al. [17].

99 For sensory acceptability, breads were placed on coded white plastic plates and served randomly. Test

100 was performed with twenty seven trained panelists (14 females and 13 male, ranging in age between 20

101 and $40 \mathrm{yr}$ ) working at the Santa Catalina Experimental Station, INIAP (Quito, Ecuador). Previous group

102 discussion was carried out to define bread characteristics and scores. A 7-point hedonic scale (1 -

103 disliked extremely, 2 - much disliked, 3 - disliked, 4 - liked and did not like, 5 - liked, 6 -a lot, 7 -

104 liked extremely) [18].

105 Statistical analysis

106 All analyses were performed in triplicate, the results are given as the mean \pm standard deviation. The

107 data were analyzed by applying multifactorial ANOVA, using INFOSTAT statistical software package

108 (Universidad de Córdoba, Argentina), to compare the means with respect to flour type and substitution

109 level. The Tukey's multiple range test was applied to determine significant differences at the 5\% level.

\section{Results and Discussion}

\section{Characteristics of debittered and fermented lupin flours and wheat-lupin doughs}

112 There were significant differences $(\mathrm{P}<0.05)$ on the proximate and minerals composition of the lupin

113 flours (Table 1). The solid-state fermentation significantly increased the protein and fat, with a

114 concomitant reduction in crude fiber, carbohydrate content and minerals (with exception of copper),

115 likely due to the metabolic activity of Rhizopus oligosporus [14]. It must be stressed that the protein

116 content was much higher than the one reported by Mubarak [4] for deffated lupin flour from Lupinus

117 albus, which could be associated to the lupin variety or the debittering process that can greatly affect the

118 nutritional profile of the flours [7]. Regarding $\mathrm{pH}$ and acidity, FLF significantly decreased the $\mathrm{pH}$ and

119 increased the TTA (Table 1). Three levels of wheat replacement with lupin flours (DLF, FLF) were

120 tested in the breadmaking process. When dough rheological properties were evaluated with the Mixolab, 
121 the type of lupin flour significantly affected, the development time, dough stability during mixing and

122 heating (C4) and dough consistency after cooling (C5) (Table 2). Water absorption values were in the 123 range reported by Mubarak [4]. DLF progressively decreased the development time when increasing the

124 substitution level, whereas FLF decreased that parameter independently on the level. Despite the gluten 125 reduction when decreasing the relative amount of $\mathrm{WF}$, dough had similar stability to wheat dough or 126 even increased with DLF. Moreover, C2 was higher in lupin-wheat doughs at the highest level tested.

127 Results suggested that lupin proteins might be incorporated into the gluten matrix and remained 128 entrapped, giving some consistency during heating. Islam et al. [19] suggested that $\beta$-conglutins of lupin could be trapped within gluten matrix even after baking, whereas the higher thermal stability of the $\alpha$ 130 conglutins might explain their no structural integration. Starch gelatinization related to C3 and its 131 stability during heating (C4) decreased in the presence of DLF but the opposite effect was observed in

132 FLF, in spite of the lower carbohydrate content of this flour (Table 1), thus starch performance might be 133 affected by the other flour constituents like the high content of proteins [20]. Again, FLF increased the 134 dough consistency after cooling (C5) and a tendency to decrease it when increasing the level of the FLF 135 flour was envisaged, but the opposite effect was observed with DLF. An increase in C5 has been 136 described when increasing amounts of debittered lupin flour (up to 25\%) were blended with wheat, 137 which was related to the interactions between wheat amylose and lupin lipids (one of the major 138 constituents) [20]. Divergences observed in the present study with DLF might be due to the adapted 139 hydration of the doughs used in this study. Nevertheless, considering the possible role of lipids in dough 140 consistency after cooling, it seems that the different lipid profile of DLF and FLF might be responsible 141 of their diverse performance [14].

\section{Breads technological properties and acceptability}


143 Lupin treatment significantly affected the specific volume and all color parameters of the crumb, being

144 the effect more marked for breads containing FLF (Table 3). Nevertheless, no significant effect on 145 specific volume was observed with $10 \%$ replacement with either of the lupin flours. Higher 146 replacements induced a significant reduction of the specific volume. These results agree with previous 147 findings, attributing that reduction to the gluten replacement by lupin proteins and the level of fiber [21, 148 6].

149 Wheat substitution with lupin significantly reduced the luminosity of the crust, and that effect was 150 intensified when increasing the levels of lupin, significantly in the case of FLF (Table 3). Similar 151 observations have been reported with other lupin-wheat breads [21]. Crumb chroma $\left(C^{*}\right)$ significantly 152 increased with both lupin flours, but a steady increase was observed when augmenting the level of FLF, 153 which could be attributed to its higher carotenoids content (544.78 $\mu \mathrm{g} / 100 \mathrm{~g})$ [14]. Similarly, Dervas et 154 al. [22] reported darker crust and yellowish crumbs at levels of substitution higher than $10 \%$ with $L$. 155 albus.

156 The lupin treatment significantly affected the textural parameters, with exception of springiness, 157 whereas the level of substitution significantly affected hardness, chewiness and resilience (Table 3). 158 Specifically, flours type significantly increased the crumb hardness at levels $>10 \%$ and reduced 159 resilience. The flour type also affected significantly the crumb cohesiveness. Compared to wheat bread, 160 DLF gave similar crumb hardness in the lupin-wheat breads up to $10 \%$ substitution, but higher level of 161 substitution resulted in great crumb hardening. Similar hardness has been reported for lupin-wheat 162 breads at those levels of substitution and it has been explained based on gluten dilution [20], which has 163 been also observed with lupin protein isolates (10\%) that gave more compact crumbs [23]. Conversely, $16410 \%$ FLF substitution gave softer crumbs, and although higher substitution resulted in crumb hardening, 165 it was lower than that of DLF. Some authors studying different varieties of lupins observed that their 166 lipid and protein profile might be responsible of attaining some textural properties similar to wheat 
167 breads [6]. Cohesiveness of the crumbs was reduced with the lupin flours but no trend was observed

168 with the level of substitution. Chewiness was even reduced in lupin-wheat breads, compared to wheat

169 bread and only DLF at $20 \%$ replacement resulted in a significant increase. Considering that chewiness is

170 inversely related to the easiness of chewing, FLF allowed obtaining more chewy protein enriched wheat

171 breads. Crumbs resilience was significantly reduced with the lupin flours, compared to wheat bread, and

172 the effect was slightly more noticeable with FLF. This decrease could be related to the low specific

173 volume of the breads, having denser crumbs with lower number of gas cells, in consequence the crumb

174 structure takes longer to recover after compression [24]. The sensory analysis carried out with those

175 breads to check acceptability indicated that only the lupin treatment significantly affected the acceptability, which was similar to wheat bread when using DLF for substitution, but decreased for FLF

177 (Table 3). Panelists attributed the lower acceptance of the FLF-wheat bread due to their acidic taste and

178 flavor. The aroma of lupin-wheat breads has been associated to oxidative degradation of fatty acids or

179 thermal reactions [5], thus the different fatty acids profile of DLF and FLF [14] might explain their

180 sensory differences. Changes in aroma and taste have been previously reported at $15 \%$ substitution with

181 L. albus [25]. Even lower levels of deffated lupin (9\%) has been reported to decrease the overall quality

182 of lupin-wheat breads due to low scoring in texture, crumb color and flavor [4].

\section{Nutritional characteristics of lupin-wheat bread}

184 Bread composition in macro and micronutrients is displayed in Table 4. The multiple factor analysis of 185 variance indicated significant differences $(\mathrm{P}<0.05)$ promoted by flour type (debittering, fermentation) of

186 lupin flour on moisture, ash, fat, crude fiber, protein and carbohydrates content, whereas the level of 187 wheat substitution by lupin additional resulted in significant variation $(\mathrm{P}<0.05)$ in most nutritional component, except in copper (data not showed). Compared to wheat bread, breads containing lupin,

189 whatever treatment, had lower moisture content, higher protein, fat and fiber content, which increased 190 with the level of wheat replacement. Despite the higher fiber content, lupin-wheat breads retained less 
moisture, likely due to the high fat content. Higher moisture content has been reported for breads made

192 with lupin previously fermented with lactic acid bacteria and used as sourdough [13]. For the same level 193 of wheat substitution (20\%), lupin enriched breads had similar composition in protein and ash than the 194 one previously reported by [ 7] when compared breads made with debittered lupin from different 195 varieties of L. angustifolius, but higher levels of fat and crude protein are obtained in the present study 196 with L. mutabilis. Unexpectedly, although FLF had higher protein content than DLF, that difference was 197 not observed in the lupin-wheat breads. Compared to wheat breads, lupin-wheat breads with FLF 198 increased the protein content by $14.71 \%, 29.75 \%$ and $30.53 \%$ when the level of substitution was $10 \%$, $19915 \%$ and $20 \%$, respectively, versus $20.31 \%, 30.0 \%$ and $32.48 \%$ obtained with same substitution of DLF. 200 Possibly, nitrogen compounds in FLF were more accessible to yeast during fermentation reducing the 201 theoretical increase. Therefore, initial differences in the nutrient composition of the debittered and 202 fermented lupin flours were not really noticeable in the resulting breads. Regarding the mineral content 203 (Table 4), the flour type and level of substitution affected significantly the amount of all minerals, with 204 exception of copper (results not shown). Nevertheless, compared with the wheat bread, lupin-wheat 205 breads had significantly higher content of calcium, phosphorus, magnesium (only FLF), iron, 206 manganese and zinc, which agrees with the high mineral content of lupin flour [26]. Again, despite the 207 significant differences observed in the lupin flours composition, no great differences were observed 208 between the resulting lupin-wheat breads.

209 The hydrolytic and glycemic indexes evaluated by in vitro methods were affected by both factors, the 210 flour type and the level of substitution (data not shown), with major impact promoted by FLF. Those 211 indexes were significantly lower than the ones obtained for wheat breads, confirming the reduced 212 digestion of the starchy compounds in lupin-wheat breads [17]. The hypoglycemic effect of the lupin213 wheat breads has already been reported and associated to the type of proteins, particularly the $\gamma$ - 
214 conglutins [27]. The effect on hydrolytic index was significantly more accentuated in FLF breads and a 215 progressive reduction was observed increasing lupin levels.

216 Other highly appreciated aspect in breads is the content in dietary fiber and lupin-wheat breads had 217 significantly higher fiber content than wheat bread, particularly in the case of DLF-wheat breads. The 218 DLF flour had significantly higher content of fiber than FLF flour (Table 1). Fiber is reduced during the 219 solid-state fermentation process because $R$. oligosporus partly used it to synthesize fats and bioactive 220 compounds required for its metabolism [14].

\section{Concluding remarks}

222 Debittered and fermented lupin flours from L. mutabilis showed good breadmaking performance at 223 dough and bread level when blended with wheat flour. Lupin-wheat breads without any significant 224 impact on the technological properties could be obtained with $10 \%$ wheat substitution. Nevertheless, to 225 further increase the quantities of protein, dietary fiber and minerals in lupin-wheat breads, substitution 226 could be increased up to $20 \%$, although with some detrimental effect on crust luminosity, specific 227 volume, crumb hardness, cohesiveness and resilience. Despite the different proximate composition of 228 debittered and solid-state fermented lupin flours, barely differences were evidenced in the nutritional 229 composition of the lupin-breads, but FLF could be used up to $20 \%$ with less impact on textural 230 properties, and greater reduction on the hydrolytic index, although the acidic taste detected by panelists 231 should be masked.

\section{Conflict of Interest}

233 The authors declare that there is no conflict of interest regarding this publication.

\section{Acknowledgments}

235 The authors would like to acknowledge the financial support of the Cooperative Program for the 236 Regional Agricultural Technology Fund (FONTAGRO) (Project FTG/RF-14893-RG, 2016-2018), 
237 Spanish Ministry of Science and Innovation (RTI2018-095919-B-C21), Generalitat Valenciana 238 (Prometeo 2017/189) and the European Regional Development Fund (FEDER).

\section{References}

1. Betoret E, Rosell C (2020) Enrichment of bread with fruits and vegetables: Trends and strategies to increase functionality. Cereal Chemistry 97: 9-19. Science 49:14-16. and technological functionality of lupin flour addition to bread and other baked products:

2. Ballester D, Zacari I, Yhlez E (1984) Baking Studies and Nutritional Value of Bread Supplemented with Full-Fat Sweet Lupine Flour (L. albus cv Multolupa ). Journal of Food

3. Villarino C, Jayasena,V, Coorey R, Chakrabarti-Bell S, Johnson S (2016) Nutritional, health, Benefits and challenges. Critical Reviews in Food Science and Nutrition 56(5): 835-857.

4. Mubarak A (2001) Chemical, nutritional and sensory properties of bread supplemented with lupin seed ( Lupinus albus ) products. Nahrung/Food 45(4): 241-245.

5. Paraskevopoulou A, Chrysanthou A, Koutidou M (2012) Characterisation of volatile compounds of lupin protein isolate-enriched wheat flour bread. Food Research International 48(2): 568-577.

6. Villarino C, Jayasena V, Coorey R, Chakrabarti-Bell S, Johnson S (2015a) Optimization of formulation and process of Australian sweet lupin (ASL)-wheat bread. LWT-Food Science and Technolog, 61(2): 359-367.

7. Villarino C, Jayasena V, Coorey R, Chakrabarti-Bell S, Foley R, Fanning K, Johnson S (2015b) The effects of lupin (Lupinus angustifolius) addition to wheat bread on its nutritional, phytochemical and bioactive composition and protein quality. Food Research International 76: $58-65$.

8. Villarino C, Jayasena V, Coorey R, Chakrabarti-Bell S, Johnson S (2014) The effects of breadmaking process factors on Australian sweet lupin-wheat bread quality characteristics. 
International journal of food science \& technology 49(11):2373-238.

9. Frick K, Kamphuis L, Siddique K, Singh K, Foley R (2017) Quinolizidine alkaloid biosynthesis in lupins and prospects for grain quality improvement. Frontiers in plant science, 8,87 .

10. Cortés-Avendaño P, Tarvainen M, Suomela J, Glorio-Paulet P, Yang B, Repo-Carrasco-Valencia Sweet after Aqueous Debittering Process. Plant Foods for Human Nutrition 1-8.

11. Jiménez-Martínez C, Campos-Mendiola R, Sánchez-Espíndola M, Jiménez-Aparicio A, Gutiérrez-López G, Dávila-Ortiz G (2009) Microstructural changes in Lupinus campestris seed in response to three thermal debittering treatments. Journal of the Science of Food and Agriculture 89(14): 2399-2404.

12. Villacrés E, Álvarez J, Rosell C (2020a) Effects of two debittering processes on the alkaloid content and quality characteristics of lupin (Lupinus mutabilis Sweet). Journal of the Science of Food and Agriculture.

13. Bartkiene E, Schleining G, Rekstyte T, Krungleviciute V, Juodeikiene G, Vaiciulyte-Funk L, Maknickiene Z, (2013) Influence of the addition of lupin sourdough with different lactobacilli on dough properties and bread quality. International journal of food science \& technology 48(12): 2613-2620.

14. Villacrés E, Quelal M, Jácome,X, Cueva G, Rosell C (2020b) Effect of debittering and solidstate fermentation processes on the nutritional content of lupin (Lupinus mutabilis Sweet). International Journal of Food Science \& Technology.

15. AOAC (Association of Official Analytical Chemestry) (1995, 2000, 2005) Official Methods of Analysis.

16. AACC International. (s.f.). (n.d.) Approved Methods of Analysis Fiber: Total Dietary Fiber 
Method 32-05.

17. Goñi I, Garcia-Alonso A, Saura-Calixto F, (1997) A starch hydrolysis procedure to estimate glycemic index. Nutrition Research 17(3): 427-437.

18. Watts B, Ylimaki G, Jeffery L, Elías L (1992) Basic methods for food evaluation. Ottawa, International Development Research. CIID, Ottawa, ON, CA. 159 p.

19. Islam, S., Ma, W., Yan, G., Gao, L., \& Appels, R. (2011). Differential recovery of lupin proteins from the gluten matrix in lupin-wheat bread as revealed by mass spectrometry and twodimensional electrophoresis. Journal of agricultural and food chemistry, 59(12), 6696-6704.

20. Rosell C, Cortez G, Repo-carrasco R (2009) Breadmaking Use of Andean Crops Quinoa, Kañiwa, Kiwicha and Tarwi. Cereal Chemistry Journal 86(4): 386-392.

21. Pollard N, Stoddard F, Popineau Y, Wrigley C, Macritchie F (2002) Lupin Flours as Additives: Dough Mixing, Breadmaking, Emulsifying, and Foaming. Cereal Chemistry Journal 79(5): 662669.

22. Dervas G, Doxastakis G, Hadjisavva-zinoviadi S, Trianta N (1999) Lupin flour addition to wheat flour doughs and effect on rheological properties. Food Chemistry 66, 67-73.

23. López E,Goldner M (2015) Influence of storage time for the acceptability of bread formulated with lupine protein isolate and added brea gum. LWT-Food Science and Technology 64(2): 1171-1178.

24. Matos M, Sanz,T, Rosell C (2014) Establishing the function of proteins on the rheological and quality properties of rice based gluten free muffins. Food Hydrocolloids 35: 150-158.

25. Campos J, El Dash A (1978) Effect of addition of full fat sweet lupine flour on rheological properties of dough and baking quality of bread. Cereal Chemistry 55, 619-625.

26. Ertaş N (2015) Technological and chemical characteristics of breads made with lupin sprouts. Quality Assurance and Safety of Crops \& Foods 7(3): 313-319. 
309 27. Sedláková K, Straková E, Suchý P, Krejcarová J, Herzig (2016) Lupin as a perspective protein 310 plant for animal and human nutrition-a review. Acta Veterinaria Brno 85(2):165-175.

311

312 
Table 1 Physical characteristics, proximate and minerals composition of debittered (DLF) and fermented (FLF) lupin flours compared to wheat flour.

\begin{tabular}{llll} 
& DLF & FLF & Wheat \\
\hline pH & $6.66 \pm 0.03^{\mathrm{b}}$ & $5.42 \pm 0.025^{\mathrm{a}}$ & $5.96 \pm 0.05^{\mathrm{a}}$ \\
TTA (mL 0.1 M NaOH)* & $0.30 \pm 0.001^{\mathrm{b}}$ & $7.75 \pm 0.002^{\mathrm{a}}$ & $0.27 \pm 0.06^{\mathrm{b}}$ \\
Moisture & $104.80 \pm 0.14^{\mathrm{b}}$ & $106.90 \pm 0.13^{\mathrm{b}}$ & $124.60 \pm 0.14^{\mathrm{a}}$ \\
Ash & $21.50 \pm 0.50^{\mathrm{a}}$ & $19.97 \pm 0.50^{\mathrm{a}}$ & $6.80 \pm 0.01^{\mathrm{b}}$ \\
Fat & $227.51 \pm 0.90^{\mathrm{b}}$ & $244.00 \pm 1.95^{\mathrm{a}}$ & $13.91 \pm 0.001^{\mathrm{e}}$ \\
Crude fiber & $137.90 \pm 3.85^{\mathrm{a}}$ & $116.40 \pm 5.14^{\mathrm{b}}$ & $12.11 \pm 0.19^{\mathrm{e}}$ \\
Protein & $546.88 \pm 1.45^{\mathrm{b}}$ & $608.15 \pm 4.35^{\mathrm{a}}$ & $144.03 \pm 0.01^{\mathrm{c}}$ \\
Total carbohydrates & $66.22 \pm 4.92^{\mathrm{b}}$ & $11.45 \pm 5.10^{\mathrm{c}}$ & $823.22 \pm 0.08^{\mathrm{a}}$ \\
Calcium & $4.00 \pm 0.40^{\mathrm{a}}$ & $2.40 \pm 0.10^{\mathrm{b}}$ & $0.10 \pm 0.01^{\mathrm{c}}$ \\
Phosphorus & $4.70 \pm 0.50^{\mathrm{a}}$ & $3.27 \pm 0.35^{\mathrm{b}}$ & $2.03 \pm 0.01^{\mathrm{c}}$ \\
Magnesium & $0.65 \pm 0.05^{\mathrm{a}}$ & $0.56 \pm 0.11^{\mathrm{b}}$ & $0.42 \pm 0.01^{\mathrm{c}}$ \\
Potassium & $0.95 \pm 0.12^{\mathrm{b}}$ & $0.11 \pm 0.02^{\mathrm{c}}$ & $11.01 \pm 0.01^{\mathrm{a}}$ \\
Sodium & $0.12 \pm 0.03^{\mathrm{b}}$ & $0.11 \pm 0.02^{\mathrm{c}}$ & $9.00 \pm 0.01^{\mathrm{a}}$ \\
Iron & $57.70 \pm 1.57^{\mathrm{a}}$ & $52.67 \pm 1.53^{\mathrm{b}}$ & $33.00 \pm 0.01^{\mathrm{c}}$ \\
Zinc & $69.96 \pm 0.14^{\mathrm{a}}$ & $29.75 \pm 1.52^{\mathrm{b}}$ & $15.00 \pm 0.01^{\mathrm{c}}$ \\
Copper & $1.83 \pm 0.22^{\mathrm{c}}$ & $2.97 \pm 0.17^{\mathrm{a}}$ & $2.00 \pm 0.01^{\mathrm{b}}$ \\
Manganese & $21.33 \pm 2.08^{\mathrm{a}}$ & $9.70 \pm 0.52^{\mathrm{c}}$ & $10.00 \pm 0.01^{\mathrm{b}}$ \\
\hline
\end{tabular}

Values followed by different letters within rows denote significant differences $(\mathrm{P}<0.05)$. Mean \pm standard deviation $(\mathrm{n}=3)$. Moisture, protein, ash, lipids, crude fiber, total carbohydrates, calcium, phosphorus, magnesium and potassium data are expressed as the $\mathrm{g} \cdot \mathrm{kg}^{-1}$ dry weight of the sample. Sodium, Iron, zinc, copper and manganese are expressed as $\mathrm{mg} \cdot \mathrm{kg}^{-1}(\mathrm{dw})$.

Table 2 Effect of wheat flour substitution by debittered (DLF) and fermented lupin (FLF) flour on rheological characteristics of dough (Mixolab profile)

Wheat

$0 \%$
DLF
FLF

Water absorption

$(\%)$

$$
64.25 \pm 0.35^{\mathrm{c}}
$$

$66.82 \pm 0.02^{\mathrm{b}} \quad 62.67 \pm 0.98^{\mathrm{c}}$

$63.43 \pm 0.07^{\mathrm{c}}$

$62.78 \pm 5.31^{\mathrm{c}}$

$70.90 \pm 0.73^{\mathrm{a}}$

$61.61 \pm 0.43^{\mathrm{d}}$

Development time (min) Stability (min) $5.28 \pm 0.00^{\mathrm{b}} \quad 7.45 \pm 1.94^{\mathrm{a}} \quad 2.60 \pm 0.68^{\mathrm{c}}$

$2.12 \pm 0.02^{\mathrm{c}}$

$1.39 \pm 0.23^{\mathrm{c}}$

$1.21 \pm 0.23^{\mathrm{c}}$

$1.08 \pm 0.01^{\mathrm{c}}$

$\mathrm{C} 2(\mathrm{Nm})$

$10.64 \pm 0.05^{\mathrm{c}}$

$11.62 \pm 0.19^{\mathrm{a}} \quad 12.05 \pm 0.04^{\mathrm{a}}$

$12.21 \pm 0.01^{\mathrm{a}}$

$11.56 \pm 1.45^{\mathrm{b}}$

$9.60 \pm 0.88^{c}$

$9.69 \pm 1.32^{\mathrm{c}}$

C3 (Nm)

$0.51 \pm 0.01^{\mathrm{b}}$

$0.53 \pm 0.05^{\mathrm{b}}$

$0.63 \pm 0.01^{\mathrm{ab}}$

$0.66 \pm 0.01^{\mathrm{a}}$

$0.58 \pm 0.04^{\mathrm{b}}$

$0.61 \pm 0.04^{\mathrm{ab}}$

$0.65 \pm 0.01^{\mathrm{a}}$

$\mathrm{C} 4(\mathrm{Nm})$

$1.61 \pm 0.01^{\mathrm{c}}$

$1.53 \pm 0.05^{\mathrm{d}}$

$1.54 \pm 0.01^{\mathrm{d}}$

$1.57 \pm 0.01^{\mathrm{d}}$

$1.84 \pm 0.01^{\mathrm{a}}$

$1.73 \pm 0.01^{\mathrm{b}}$

$1.71 \pm 0.05^{\mathrm{b}}$

C5 (Nm)

$$
1.29 \pm 0.04^{\mathrm{b}}
$$

$1.06 \pm 0.06^{\mathrm{c}}$

$1.06 \pm 0.05^{\mathrm{c}}$

$1.03 \pm 0.04^{\mathrm{c}}$

$1.79 \pm 0.03^{\mathrm{a}}$

$1.77 \pm 0.03^{\mathrm{a}}$

$1.68 \pm 0.01^{\mathrm{b}}$

Values followed by different letters within rows denote significant differences $(\mathrm{P}<0.05)$. Mean \pm standard deviation $(\mathrm{n}=3)$.

C2: Protein weakening, C3: Starch gelatinization, C4: amylase activity, C5: starch retrogradation 
Table 3 Effect on wheat flour substitution by debittered (DLF) and fermented (FLF) lupin flour on technological properties and acceptability of bread

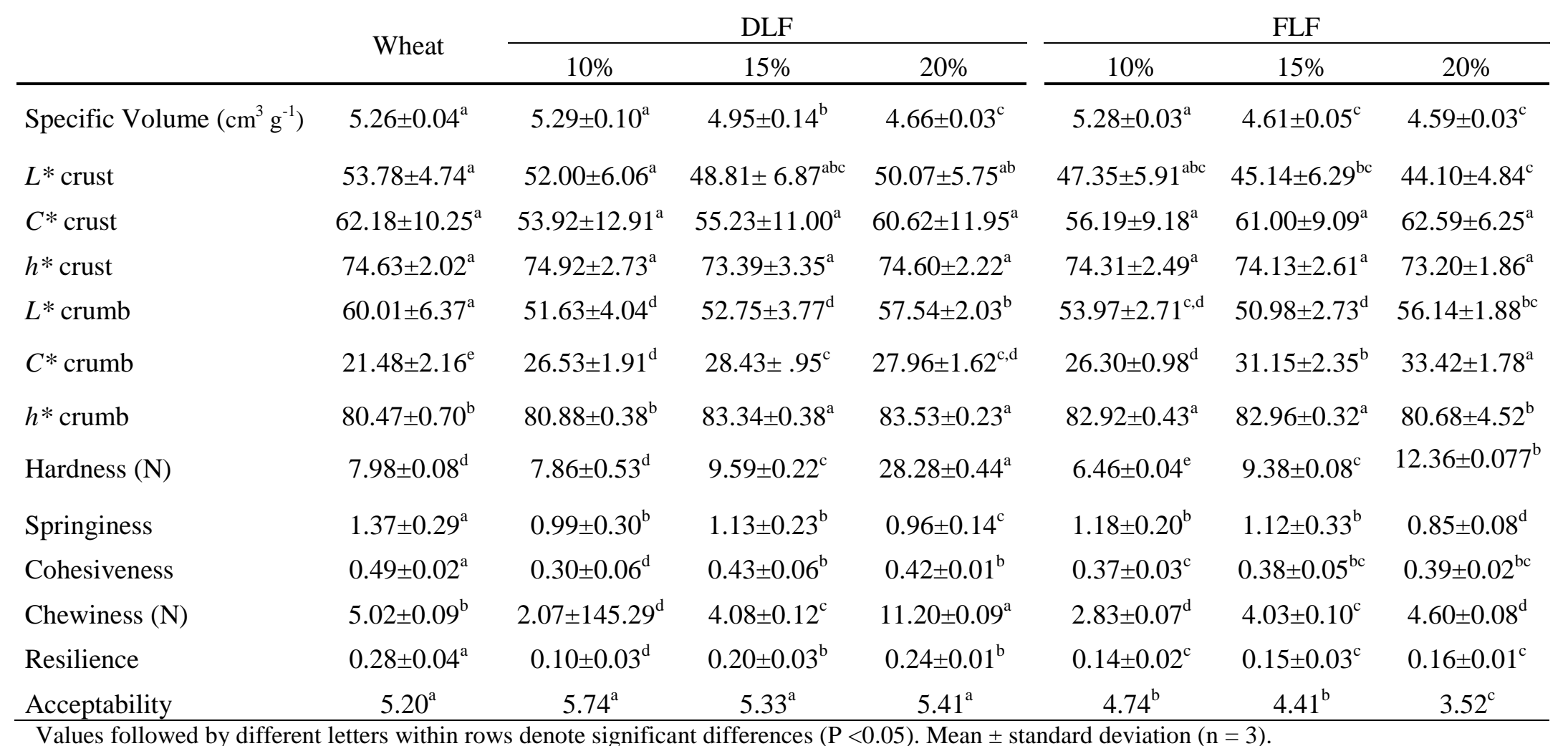


Table 4 Effect on wheat flour substitution by debittered (DLF) and fermented (FLF) lupin flour on proximate (expressed as percentage), mineral composition, glycemic and hydrolytic index of bread.

DLF

\begin{tabular}{|c|c|c|c|c|}
\hline & \multirow{2}{*}{ Wheat } & \\
\hline & & $10 \%$ & $15 \%$ & $20 \%$ \\
\hline Moisture & $371.00 \pm 0.44^{\mathrm{a}}$ & $344.61 \pm 1.93^{b}$ & $349.70 \pm 2.10^{b}$ & $314.82 \pm 3.56^{\mathrm{d}}$ \\
\hline Ash & $24.71 \pm 0.05^{\mathrm{b}}$ & $25.30 \pm 0.08^{\mathrm{b}}$ & $25.82 \pm 0.05^{\mathrm{ab}}$ & $27.11 \pm 0.05^{\mathrm{a}}$ \\
\hline Fat & $45.82 \pm 0.13^{\mathrm{e}}$ & $78.20 \pm 1.10^{c}$ & $80.11 \pm 0.88^{b}$ & $99.50 \pm 2.04^{\mathrm{a}}$ \\
\hline Crude Fiber & $11.70 \pm 0.12^{\mathrm{b}}$ & $27.12 \pm 0.13^{b}$ & $32.04 \pm 1.09^{\mathrm{a}}$ & $35.80 \pm 2.01^{\mathrm{a}}$ \\
\hline Protein & $153.63 \pm 0.30^{\mathrm{d}}$ & $184.80 \pm 0.18^{\mathrm{b}}$ & $199.71 \pm 0.64^{\mathrm{a}}$ & $203.50 \pm 0.21^{\mathrm{a}}$ \\
\hline Carbohydrates & $768.61 \pm .00^{\mathrm{a}}$ & $684.63 \pm 0.68^{c}$ & $662.40 \pm 0.95^{\mathrm{d}}$ & $634.11 \pm 1.57^{\mathrm{e}}$ \\
\hline Calcium & $0.42 \pm 0.02^{\mathrm{d}}$ & $1.05 \pm 0.03^{c}$ & $1.22 \pm 0.04^{\mathrm{c}}$ & $1.32 \pm 0.04^{\mathrm{b}}$ \\
\hline Phosphorus & $2.74 \pm 0.02^{\mathrm{d}}$ & $2.90 \pm 0.02^{\mathrm{c}}$ & $3.12 \pm 0.02^{\mathrm{b}}$ & $3.22 \pm 0.02^{\mathrm{a}}$ \\
\hline Magnesium & $0.80 \pm 0.01^{\mathrm{c}}$ & $0.71 \pm 0.01^{\mathrm{d}}$ & $0.83 \pm 0.01^{\mathrm{b}}$ & $0.80 \pm 0.01^{\mathrm{c}}$ \\
\hline Potassium & $12.30 \pm 0.02^{\mathrm{b}}$ & $12.33 \pm 0.02^{b}$ & $12.60 \pm 0.02^{\mathrm{a}}$ & $12.82 \pm 0.02^{\mathrm{a}}$ \\
\hline Sodium & $20.00 \pm 0.02^{b}$ & $20.00 \pm 0.02^{b}$ & $21.00 \pm 0.02^{\mathrm{a}}$ & $21.00 \pm 0.02^{\mathrm{a}}$ \\
\hline Copper & $2.03 \pm 0.02$ & $2.00 \pm 0.02$ & $2.00 \pm 0.02$ & $2.00 \pm 0.02$ \\
\hline Iron & $56.00 \pm 0.02^{\mathrm{f}}$ & $97.00 \pm 0.02^{\mathrm{e}}$ & $101.00 \pm 0.02^{\mathrm{d}}$ & $101.00 \pm 0.02^{\mathrm{d}}$ \\
\hline Manganese & $16.00 \pm 0.02^{\mathrm{d}}$ & $17.00 \pm 0.02^{\mathrm{c}}$ & $17.00 \pm 0.02^{c}$ & $18.00 \pm 0.02^{b}$ \\
\hline Zinc & $18.00 \pm 0.02^{\mathrm{f}}$ & $23.00 \pm 0.02^{c}$ & $24.00 \pm 0.02^{\mathrm{b}}$ & $25.00 \pm 0.02^{\mathrm{a}}$ \\
\hline Hydrolytic index & $100.00 \pm 0.00^{\mathrm{a}}$ & $51.96 \pm 10.96^{\mathrm{b}}$ & $50.12 \pm 16.60^{b}$ & $49.90 \pm 20.44^{b}$ \\
\hline Glycemic index & $94.61 \pm 0.00^{\mathrm{a}}$ & $68.24 \pm 5.98^{b}$ & $61.07 \pm 9.11^{\mathrm{c}}$ & $60.11 \pm 11.22^{c}$ \\
\hline Dietary fibre* & $52.8 \pm 0.12^{\mathrm{e}}$ & $282.5 \pm 0.13^{\mathrm{cd}}$ & $466.7 \pm 1.09^{b}$ & $581.8 \pm 2.01^{\mathrm{a}}$ \\
\hline
\end{tabular}

FLF

\begin{tabular}{ccc}
\multicolumn{3}{c}{ FLF } \\
\hline $10 \%$ & $15 \%$ & $20 \%$ \\
\hline $304.61 \pm 0.15^{\mathrm{e}}$ & $334.60 \pm 1.18^{\mathrm{c}}$ & $307.22 \pm 2.17^{\mathrm{de}}$ \\
$24.72 \pm 0.02^{\mathrm{b}}$ & $26.00 \pm 0.06^{\mathrm{ab}}$ & $27.04 \pm 0.07^{\mathrm{a}}$ \\
$74.72 \pm 1.59^{\mathrm{d}}$ & $81.30 \pm 1.59^{\mathrm{b}}$ & $96.92 \pm 1.60^{\mathrm{a}}$ \\
$22.73 \pm 1.12^{\mathrm{c}}$ & $28.82 \pm 1.41^{\mathrm{b}}$ & $33.52 \pm 0.26^{\mathrm{a}}$ \\
$176.20 \pm 0.07^{\mathrm{c}}$ & $199.31 \pm 0.30^{\mathrm{a}}$ & $200.51 \pm 0.16^{\mathrm{a}}$ \\
$701.70 \pm 0.59^{\mathrm{b}}$ & $664.62 \pm 0.91^{\mathrm{d}}$ & $642.11 \pm 0.85^{\mathrm{e}}$ \\
$1.10 \pm 0.03^{\mathrm{c}}$ & $1.33 \pm 0.04^{\mathrm{b}}$ & $1.42 \pm 0.04^{\mathrm{a}}$ \\
$3.04 \pm 0.02^{\mathrm{b}}$ & $3.33 \pm 0.02^{\mathrm{a}}$ & $3.40 \pm 0.02^{\mathrm{a}}$ \\
$0.93 \pm 0.01^{\mathrm{a}}$ & $0.90 \pm 0.01^{\mathrm{a}}$ & $0.91 \pm 0.01^{\mathrm{a}}$ \\
$12.31 \pm 0.02^{\mathrm{b}}$ & $12.60 \pm 0.02^{\mathrm{a}}$ & $12.72 \pm 0.02^{\mathrm{a}}$ \\
$19.00 \pm 0.02^{\mathrm{c}}$ & $19.00 \pm 0.02^{\mathrm{c}}$ & $20.00 \pm 0.02^{\mathrm{b}}$ \\
$2.01 \pm 0.02^{\mathrm{a}}$ & $2.01 \pm 0.02^{\mathrm{a}}$ & $2.01 \pm 0.02^{\mathrm{a}}$ \\
$107.00 \pm 0.02^{\mathrm{c}}$ & $110.00 \pm 0.02^{\mathrm{b}}$ & $121.00 \pm 0.02^{\mathrm{a}}$ \\
$17.00 \pm 0.02^{\mathrm{c}}$ & $18.00 \pm 0.02^{\mathrm{b}}$ & $19.00 \pm 0.02^{\mathrm{a}}$ \\
$20.00 \pm 0.02^{\mathrm{e}}$ & $22.00 \pm 0.02^{\mathrm{d}}$ & $24.00 \pm 0.02^{\mathrm{b}}$ \\
$49.45 \pm 6.77^{\mathrm{b}}$ & $45.14 \pm 2.52^{\mathrm{c}}$ & $39.76 \pm 2.67^{\mathrm{d}}$ \\
$66.86 \pm 3.72^{\mathrm{b}}$ & $64.49 \pm 1.39^{\mathrm{b}}$ & $61.54 \pm 1.46^{\mathrm{c}}$ \\
$215.5 \pm 1.12^{\mathrm{d}}$ & $475.7 \pm 0.26^{\mathrm{b}}$ & $350.1 \pm 1.41^{\mathrm{c}}$ \\
\hline
\end{tabular}

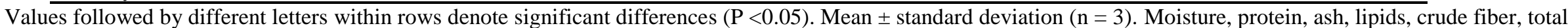

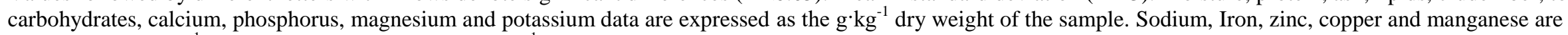
expressed as $\mathrm{mg} \cdot \mathrm{kg}^{-1}(\mathrm{dw})$. * Data are expressed as $\mathrm{g} \cdot \mathrm{kg}^{-1}$ dry weight of the sample. 